\title{
Evaluating Senior High School English Language Teachers' Perception and Practices Regarding Learner Autonomy
}

\author{
Sudarsono \\ Universitas Negeri Surabaya \\ Surabaya, Indonesia \\ sudarso@mhs.unesa.ac.id
}

\author{
Lies Amien Lestari \\ Universitas Negeri Surabaya \\ Surabaya, Indonesia \\ lieslestari@unesa.ac.id
}

\begin{abstract}
Learner autonomy (LA) is still as an interesting and trending topic for English Language practitioners, either for teachers or researchers. Promoting learner autonomy should be begun earlier at all levels of age at school or at home. This research paper reports the findings of how senior high school English teachers perceived the concept of LA and the extent of English teaches' practices to promote $L A$. The participants were 33 private and state Senior High School English teachers who joined MGMP program. The data, collected through questionnaire and interview, was analyzed using descriptive statistic. The findings revealed that 97\% participants agreed or strongly agreed that independent study in the library was an activity which developed learner autonomy; $94 \%$ of participants agreed or strongly agreed that learner autonomy was promoted when learners had some choice in the kinds of activities they did; $88 \%$ of participants agreed or strongly agreed that language learners of all ages could develop learner autonomy; $82 \%$ participants often or always performed activities to promote learner autonomy such as encouraging students not be afraid to make mistakes and asking students to do co-operative and peer learning wherever possible. This study implicated in the teachers' professional development and to learner autonomy promotion at senior high school level.
\end{abstract}

Keywords-English teachers; perception; practice, promote; learning autonomy

\section{INTRODUCTION}

Since National Curriculum of K-13 was launched, there has been a principle change of teacher's mindset in the way of teaching. The K-13 emphasizes learner-centered approach that gives students more portions of learning activities in the classroom. The teachers are encouraged to provide students wider space of activities that enables students to be more motivated, initiative, creative and independent in learning. Meanwhile, the teacher's role is as a learning facilitator for the students [7]. This government policy becomes a momentum for English teachers to find some instructional approaches which meet the K-13's principals. One of the instructional approaches recently become a trending topic is learner autonomy (LA).

Autonomy, in the context of learning, is defined as the capacity to control one's own learning, to take a charge of or to be responsible for their own learning [2][10][5][6]. However, the definition mostly often quoted is from Holec [6] that autonomy is defined as 'the ability to take charge of one's own learning. Benson [1] says that for language learner autonomy, the capacity to make informed choices and decisions about their learning is important to persistence and success. He even argues that the choices and decisions are two important issues to autonomy for language learning, especially to the development of learner autonomy and professional development [1].

The present study focused on the evaluation of senior high school teachers' perceptions regarding LA and the teachers' practices to promote LA. In the last decade, many research on the similar area were conducted by Asian researchers, but they mostly involved teachers at university level [8][11][12][13][14][15]. An Indonesian researcher identified active in doing research focusing on teachers' beliefs and its implementation regarding learner autonomy was Lengkanawati [6]. In her recent research, she investigated that the teachers had more positive perceptions regarding LA. It was indicated by their strong agreements on the statements regarding LA related to the views on technology, psychology, politic and sociocultural.

This study was undertaken to find clear understanding of senior high school English teachers' perception of learner autonomy that could contribute to actual practices performed inside or outside the classroom. This paper will first report teachers' perception regarding LA and, second, the extent to which teachers' practices promote LA based on the data of questionnaire. The results of interview will support and validate the findings investigated from the data of questionnaire.

\section{Research Question}

1. How do senior high school teachers perceive the notion of LA?

2. To what extent do the teachers' practices promote LA?

\section{METHOD}

\section{A. Participants}

The participants of this research were 33 senior high school teachers selected purposely from those who joined in MGMP (Musyawah Guru Mata Pelajaran) or Deliberation of Subject Teachers of English Language in Jember. They were coming from 16 SMA Negeri or State Senior High Schools and 7 SMA Swasta or Private Senior High Schools. They were included 16 males and 17 females. They commonly held graduate qualifications and some of were post graduate ones. Their teaching experience ranged from 3 to 32 years. Their ages ranged from 31 to 57 years old. Their qualifications were 4 masters and 29 bachelors. 


\section{B. Instrument}

This research used questionnaire and interview to get the data. 37 items of Borg and Al-Busaidi's questionnaire [3] were adopted to get the data about LA concepts perceived by the English Language Teachers of senior high school in Jember Indonesia containing. The items were divided into five categories/views: technical, political, psychological and social. The rest of the items were realted to other factors: teacher role, ages, English proficiency, culture, learning achievement, teaching approach [11]. The second questionnaire was about teachers' practices to promote learner autonomy containing 20 items [3]. The response choices to the both questionnaires were designed in the form of linkert scale with five items. Open ended interview was also performed to get the data about their own classroom practices. The interviewees were comprised six teachers selected from the 33 participants represented the overall composition of the participants, mainly in the aspects of teaching experience, age, school status and qualification.

\section{RESULTS AND DISCUSSION}

\section{A. Results}

The research findings based on each research question are briefly reported in this section. The findings are drawn from the teachers' responses to the questionnaires and from their comments as a response to the interview stage.

\section{Research Question 1: Teachers' Perception Regarding Learner Autonomy}

Table I. shows the data about participants' perception regarding learner autonomy categorized into four views: political, social, technical and psychological. The statements are represented by number to minimize the available space usage.

TABLE I. STATISTICS OF PARTICIPANTS' PERCEPTION REGARDING LEARNER AUTONOMY BY VIEW

\begin{tabular}{|c|c|c|c|c|c|c|}
\hline \multirow{2}{*}{ Views } & \multirow{2}{*}{$\begin{array}{c}\text { Statem } \\
\text { ent } \\
\text { Numb } \\
\text { er }\end{array}$} & \multicolumn{5}{|c|}{ Percentage of Responses } \\
\hline & & SDA & DA & $\mathrm{U}$ & A & SA \\
\hline Political View & 3 & $0 \%$ & $0 \%$ & $6 \%$ & $39 \%$ & $55 \%$ \\
\hline Social View & 16 & $0 \%$ & $6 \%$ & $0 \%$ & $48 \%$ & $45 \%$ \\
\hline Technical View & 2 & $0 \%$ & $3 \%$ & $0 \%$ & $42 \%$ & $55 \%$ \\
\hline $\begin{array}{c}\text { Psychological } \\
\text { View }\end{array}$ & 11 & $0 \%$ & $0 \%$ & $6 \%$ & $55 \%$ & $39 \%$ \\
\hline
\end{tabular}

Note: $S D A=$ Strongly Disagree, $D A=$ Disagree, U=Unsure, A=Agree, $S A=$ Strongly Agree

Among the six views above, technical view got the most majority response, $97 \%$ of the participants agree or strongly agree to the statement no. 2 that independent study in the library was an activity which developed learner autonomy. The response was supported by the participants' comments, such as:

"I often ask my students to go to library, especially when their teacher doesn't come. I think library is a place where students can study to develop themselves and read any book they like." (T3)
The second majority responses belonged to political view and psychological view. Both views got $94 \%$ agree or strongly agree. Statement no. 3 in political view stated that LA was promoted through regular opportunities for learners to complete tasks alone. The following comment strengthens the response.

"I think autonomy is a kind of freedom for the students to decide how they learn the material. They want to find the suitable way of learning they like." (T4)

In psychological view, the first majority participants (94\%) agreed or strongly agreed with the perception no. 11 saying that confident language learners were more likely to develop autonomy than those who lacked confidence. The interviewee' comment supported the response was:

"I belief that learners who have high confidence and get self-motivated will be easier to be learner autonomy." (T3)

In social view, majority participants (93\%) agreed or strongly agreed with the perception that LA was promoted through activities which give learners opportunities to learn from each other. The participant's comment supported the finding was:

"Some task given by the teachers could be done or solved together among the learners without any teachers' assistance." (T1)

Out of the four views, the rest of questionnaire items are categorized into six factors: teacher role, ages, English proficiency, culture, learning achievement, teaching approach. The extent to which their perception of LA related to the six factors are listed in the following table.

TABLE II. ENGLISH TEACHERS' PERCEPTION ABOUT LA IN RELATIONSHIP TO OTHER FACTORS

\begin{tabular}{|c|c|c|c|c|c|c|}
\hline \multirow[t]{2}{*}{ Factors } & \multirow{2}{*}{$\begin{array}{c}\text { State } \\
\text { ment } \\
\text { Num } \\
\text { ber }\end{array}$} & \multicolumn{5}{|c|}{ Percentage of Responses } \\
\hline & & SDA & DA & $\mathrm{U}$ & $\mathrm{A}$ & SA \\
\hline Teacher Role & 8 & $9 \%$ & $55 \%$ & $12 \%$ & $21 \%$ & $3 \%$ \\
\hline Ages & 1 & $0 \%$ & $3 \%$ & $9 \%$ & $73 \%$ & $15 \%$ \\
\hline $\begin{array}{c}\text { English } \\
\text { Proficiency }\end{array}$ & 36 & $6 \%$ & $21 \%$ & $12 \%$ & $48 \%$ & $12 \%$ \\
\hline Culture & 13 & $0 \%$ & $6 \%$ & $15 \%$ & $48 \%$ & $30 \%$ \\
\hline \multirow{2}{*}{$\begin{array}{c}\text { Learning } \\
\text { Achievement }\end{array}$} & 5 & $0 \%$ & $6 \%$ & $36 \%$ & $39 \%$ & $18 \%$ \\
\hline & 36 & $0 \%$ & $12 \%$ & $9 \%$ & $55 \%$ & $24 \%$ \\
\hline \multirow{2}{*}{$\begin{array}{l}\text { Teaching } \\
\text { Approach }\end{array}$} & 12 & $0 \%$ & $9 \%$ & $18 \%$ & $45 \%$ & $27 \%$ \\
\hline & 17 & $9 \%$ & $30 \%$ & $39 \%$ & $15 \%$ & $6 \%$ \\
\hline
\end{tabular}

Note: $S D A=$ Strongly Disagree, $D A=$ Disagree, U=Unsure, A=Agree, $S A=$ Strongly Agree

Regarding Teacher Role factor, majority participants $(65 \%)$ disagreed or strongly disagreed to the perception that learner autonomy meant learning without a teacher; only $24 \%$ for those who agreed or strongly with that statement. As Age Factor was chosen, the majority participants (88\%) agreed or strongly agreed with the perception that language learners of all 
ages could develop learner autonomy. The majority perception of the participants to the Factor of Culture (78\%) agreed or strongly agreed that LA could be achieved by learners of all cultural backgrounds. In the factor of Learning Achievement, majority participants (79\%) agreed or strongly agreed to the concept that LA had a positive effect on success as a language learner. In the Factor of Teaching Approach, majority participants $(72 \%)$ agreed or strongly agreed with the concept that LA was promoted when learners could choose their own learning materials. The majority perception of the participants to the Factor of English Proficiency (60\%) agreed or strongly agreed that Learner autonomy has a positive effect on success as a language learner

Some of participants' comments support the above findings are highlighted below.

"I belief that the teacher's presence is still required to assist learners when they are working their tasks." (T1)

"I don't know if Indonesian students from any cultural background/ ethnic can be learner autonomy, but I belief they can when they are given chances and encouragement to practice." (T3)

\section{Research Question 2: The extent to which Teachers' Practices Promote LA}

Table III shows the data about teachers'practices promote LA in their schools. The data is displayed in sequence, from the highest to the lowest frequence of practices that are comprised from $\mathrm{O}$ (often) and A (always) options. The statement of practices are represented with number in line with the original number of statements stated in questionnaire.

TABLE III. ENGLISH TEACHERS' PRACTICES TO PROMOTE LA

\begin{tabular}{|c|c|c|c|c|c|c|}
\hline \multirow{2}{*}{$\begin{array}{c}\text { No } \\
\cdot\end{array}$} & $\begin{array}{c}\text { Stateme } \\
\text { nt } \\
\text { Number }\end{array}$ & \multicolumn{5}{|c|}{ Percentage of Responses } \\
\cline { 3 - 7 } & $\mathrm{N}$ & $\mathrm{R}$ & $\mathrm{S}$ & $\mathrm{O}$ & $\mathrm{A}$ \\
\hline $\mathbf{1}$ & 4 & $0 \%$ & $0 \%$ & $0 \%$ & $36 \%$ & $64 \%$ \\
\hline $\mathbf{2}$ & 3 & $0 \%$ & $0 \%$ & $18 \%$ & $48 \%$ & $34 \%$ \\
\hline $\mathbf{3}$ & 2 & $0 \%$ & $0 \%$ & $18 \%$ & $61 \%$ & $21 \%$ \\
\hline $\mathbf{4}$ & 15 & $0 \%$ & $0 \%$ & $18 \%$ & $58 \%$ & $24 \%$ \\
\hline $\mathbf{5}$ & 9 & $0 \%$ & $0 \%$ & $27 \%$ & $52 \%$ & $24 \%$ \\
\hline
\end{tabular}

The data in table III shows the rank of practices performed by the English teachers regarding LA. Rank 1 to 5 are the practices that $\geq 75 \%$ of participants often performed. Start from rank 1, statement number 4 reveals that $100 \%$ of participants often or always encouraged their students to be more responsible about what they did in class. It was the most often practiced by the teachers and they believed that it could promote LA. There were three practices (statement number 3, 2 and 15) which $82 \%$ of participants often or always performed: a) encouraging students to go the extra mile and not be afraid to make mistakes, going a long way in making them confident to work by themselves, b) asking students to do co-operative and peer learning wherever possible; and c) telling students that knowledge was always available around them, but all that they need were the incentive and the method to find it. Rank 5, statement number 9, was LA practice that $75 \%$ of the teachers mostly performed. They did their best to involve their students in reflection into students' individual learning preferences and strategies. Those findings were supported with following comments:

"Class is a place where they can interract each other; example, discussion, doing tasks etc. students should be responsible to what they have done." (T1)

The following statements are examples of other activities performed by the participants out of the 20 activities listed in the questionnaire that they believed to be able to promote LA.

"Playing some funny short films and asking students to see them and give comments about what they have seen." (T5)

The teachers' critical statements above are only the ones that are regarded different from one to another; meanwhile, the statements that are regarded similar are not reported.

\section{B. Discussion}

The findings of the current study revealed that the teachers' perception represents their understanding on the concept of LA mostly lead to technical view first, and then followed by political view, psychological view and, the last, social view. Borg and Busaidi's [3] research reported the result differently. The most agreed was psychological view, and then followed by political, technical and finally social. In this study, the orientation of the agreement mostly addressed to technical view was affected by the participants' understanding about the concept of LA. They knew LA as independent study that was mostly related to the way of learning, more mechanical.

In the context of Asean countries, Indonesian senior high school English teachers held a bit different perception on the notion of LA with teachers in other Asean countries. In Vietnam, for example, the statement covered in Political View that " autonomy means that learners can make choices about how they learn," (statement 4) was agreed or strongly agreed by $77.4 \%$ of majority Vietnam's teacher [11] and by $83 \%$ of Cambodian ELT teachers [8].

The statement about language learners of all ages could develop learner autonomy was perceived by $88 \%$ of majority participants. It refers to a concept theorized by Benson [1] that promoting LA in second or foreign language teaching is, in fact, begun at early age. It was also proved by the participants when they were asked to vote whether they agreed that it was harder to promote learner autonomy with proficient language learners than it was with beginners, more than a half of them $(52 \%)$ agreed or strongly agreed. Thus, developing LA for foreign or second language learner should be begun early age.

The teachers' practice regarding LA that all participants often or always performed was encouraging their students to be more responsible about what they did in class. What the teachers often practiced so far was a psychological encouragement as they believed it could promote students to be autonomous learners. 


\section{CONCLUSION}

The major finding of this research was that the senior high school English teachers had good perceptions about the concept of LA based on their own understanding, although they had not received any preliminary lecturing regarding LA. They gave majority agree or strongly agree with the statements that, perhaps, theoretically they rarely read. Their good perceptions could be considered as an important component to develop learner autonomy. They admitted doing practical and encouraging activities to promote LA. Their admittances indicated a positive effort to engage their students in out-side or inside the classroom tasks so as to increase autonomous behaviors. The teachers' better understanding on LA principles was believed to lead to their better practical performances regarding LA development.

\section{REFERENCES}

[1] P. Benson, Language Learner Autonomy: Exploring Teachers' Perspectives on Theory and Practices. In Barnard, R. and J. Li (Eds.) Language Learner Autonomy: Teachers' Beliefs and Practices in Asian Context (pp. xxxiii-xlii).Phnom Penh: IDP Education (Cambodia) Ltd., 2016.

[2] P. Benson, Teaching and Researching Autonomy (2nd ed). London, England: Pearson Education, 2011.

[3] S. Borg, and S. A. Busaidi, "Teachers' Beliefs and Practices Regarding Learner Autonomy," English Language Teaching Journal, 33 (3), 283-292, [Online]. Available at http://dx.doi.org/10.1093/elt/ccr065, 2012a.

[4] Borg, S. and Al Busaidi, S., Learner Autonomy: English Language Teachers' Belief and Practices (ELT Research Paper 12-07). London England: British Council, 2012b.

[5] L, Dickinson, Self-instruction in Language Learning. New York: Cambridge University Press, 1987.

[6] H. Holec, Autonomy and Foreign Language Learning. Oxford, England: Pergamon, 1981.

[7] Kemendikbud., Konsep dan Implementasi Kurikulum 2013. [Online]. Available http://kemdikbud.go.id/kemdikbud/dokumen/Paparan/ Paparan\%20Wamendik.pdf, 2014.
[8] C. N. Keuk, and V. Heng, Cambodian ELT Teachers Through Professional Development. In Barnard, R. and J. Li (Eds.) Language Learner Autonomy: Teachers' Beliefs and Practices in Asian Context (pp. 62-78).Phnom Penh: IDP Education (Cambodia) Ltd, 2016.

[9] N. S. Lengkanawati, Teachers' Belief about Learner Autonomy and Its Implementation in Indonesian EFL Setting. In Barnard, R. and J. Li (Eds.) Language Learner Autonomy: Teachers' Beliefs and Practices in Asian Context (pp. 134-149).Phnom Penh: IDP Education (Cambodia) Ltd., 2016.

[10] D. Little, Learner Autonomy: Definitions, Issues and Problem. Dublin, UK: Authentic, 1991.

[11] N. V. Loi, Learner Autonomy in Vietnam: Exploring Teacher Perspective and Practice. In Barnard, R. and J. Li (Eds.) Language Learner Autonomy: Teachers' Beliefs and Practices in Asian Context (pp. 1-8). Phnom Penh: IDP Education (Cambodia) Ltd., 2016.

[12] M. R. T. Madrunio, V. N. Tupas, and P. N. R. Valdez, Learner Autonomy: English Language Teachers'Beliefs and in the Philipines. In Barnard, R. and J. Li (Eds.) Language Learner Autonomy: Teachers' Beliefs and Practices in Asian Context (pp. 114-133).Phnom Penh: IDP Education (Cambodia) Ltd, 2016.

[13] R. Stroupe, Roundle, and K. C. Tomita, K., Developing Autonomous Leaner in Japan: Working with Teachers Through Professional Development. In Barnard, R. and J. Li (Eds.) Language Learner Autonomy: Teachers' Beliefs and Practices in Asian Context (pp. 43-61).Phnom Penh: IDP Education (Cambodia) Ltd., 2016.

[14] T. Tapinta, Thai Teachers' Beliefs in Developing LearnerAutonomy: L2 Education in Thai Universities. In Barnard, R. and J. Li (Eds.) Language Learner Autonomy: Teachers' Beliefs and Practices in Asian Context (pp. 98-113).Phnom Penh: IDP Education (Cambodia) Ltd., 2016.

[15] Y. Wang, and M. Wang, Developing Learner Autonomy: Chinese University EFL Teachers' Perception and Practices. In Barnard, R. and J. Li (Eds.) Language Learner Autonomy: Teachers' Beliefs and Practices in Asian Context (pp. 23-42).Phnom Penh: IDP Education (Cambodia) Ltd., 2016. 